\title{
О.В. Усмінська
}

\section{ПАЛЕОГЕОГРАФІЧНІ ОБСТАНОВКИ ОСАДКОНАГРОМАДЖЕННЯ В МІОЦЕНІ ЦЕНТРАЛЬНОЇ ЧАСТИНИ ВОЛИНО-ПОДІЛЛЯ}

\author{
O.V. Usminska
}

\section{PALAEOGEOGRAPHICAL ENVIRONMENT OF SEDIMENTATION IN MIOCENE OF THE CENTRAL PART OF VOLYNO-PODILLYA REGION}

Стаття присвячена історії геологічного розвитку та палеогеографічним обстановкам осадконагромадження в неогеновий час на сучасній території району верхньої течії р. Серет (аркуш "Тернопіль»). Вивчені результати робіт попередніх дослідників, уточнені з урахуванням новітніх даних - вивчення керну свердловин останніх геологозйомочних робіт та на основі діючих Легенди [4] та Стратиграфічної схеми [5].

Ключові слова: Волино-Поділля, неогенова система, палеогеографія.

Статья посвящена истории геологического развития и палеогеографическим обстановкам осадконакопления в неогеновое время на современной территории района верхнего течения р. Серет (лист “Тернополь»). Изучены результаты работ предыдущих исследователей, уточненные с учетом новейших данных - изучение керна скважин последних геологосъемочных работ и на основе действующих Легенды [4] и Стратиграфической схемы [5].

Ключевые слова: Волыно-Подолье, неогеновая система, палеогеография.

The article is devoted to the history of geological development and to palaeogeographical environment of sedimentation in Neogene time in the modern area on the upper part of the Seret river. We have examined the results of previous investigators which were clarified according to the newest facts: to the investigation of boreholes core, to the latest geological surveys and to the valid Legend [4] and Scheme of stratigraphy [5].

Keywords: Volhyn'-Podhillia region, Neogene, palaeogeography.

ВСТУП

Відклади неогенової системи значно поширені і залягають горизонтально з кутовою та стратиграфічною неузгодженостями на відкладах верхньої крейди та палеозою. Виходи утворень неогену на денну поверхню спостерігаються по усіх річкових долинах і численних ярах, а на закритих площах вододілів вони розкриті значною кількістю свердловин. В даній роботі відтворено історію геологічного розвитку та дана загальна характеристика палеогеографічних обстановок, що панували протягом міоцену на досліджуваній території.

Актуальність роботи полягає в тому, що відтворення палеогеографічних обстановок формування міоценових утворень Волино-Поділля дозволяє 3'ясувати фізико-географічні умови формування відкладів та встановити зв'язки різноманітних покладів корисних копалин з відповідними умовами осадконагромадження.

Основні напрямки досліджень: ревізія результатів раніше проведених робіт, визначення належності певних стратонів та їх груп до відповідних фаціальних типів, простеження їх латералі та у розрізі, кореляція та ув'язка з суміжними територіями.
Для виконання мети досліджень було переглянуто та проаналізовано увесь доступний фактичний матеріал попередніх дослідників (як тематичні, так і геологозйомочні роботи), а також використано результати власних польових спостережень.

Коротка історія досліджень неогенових відкладів. Перші свідчення про геологію району з'являються у роботах Ейхвальда Е. (1823р.), Яковицького І. (1830р.), Барбота-де-Марні І.П. (1867 р.), Михальського А.О. (1895р.), Ломницького М. (1897р., 1901 р.), Тейссейера В. (1900р.), Ласкарева В.Д. (1914р.). В подальшому у різні роки даною проблематикою займалися Фрідберг В. (1911-1930рр.), Новак Я. (1907-1939рр.), Чарноцький Я. (1933р.), Утробін В.Н. (1950-1951 рр.), Королюк І.К. (1952 р.), Горецький В.А. (1954 р.), Кудрін Л.Н. (1954-1960рр.), Дідківський В.Я. (1964р.) [6] . Геологозйомочні роботи на даній території проводили Власов Б.І. (1962р.) [2], Грузман Г.Г. (1988р.) [3], ряд інших дослідників, які приділяли увагу або дослідженням на окремих родовищах, або повністю були зорієнтовані на певний вид корисних копалин. Останні за часом геологозйомочні роботи для досліджуваної території

(с) О.В. Усмінська, 2010 


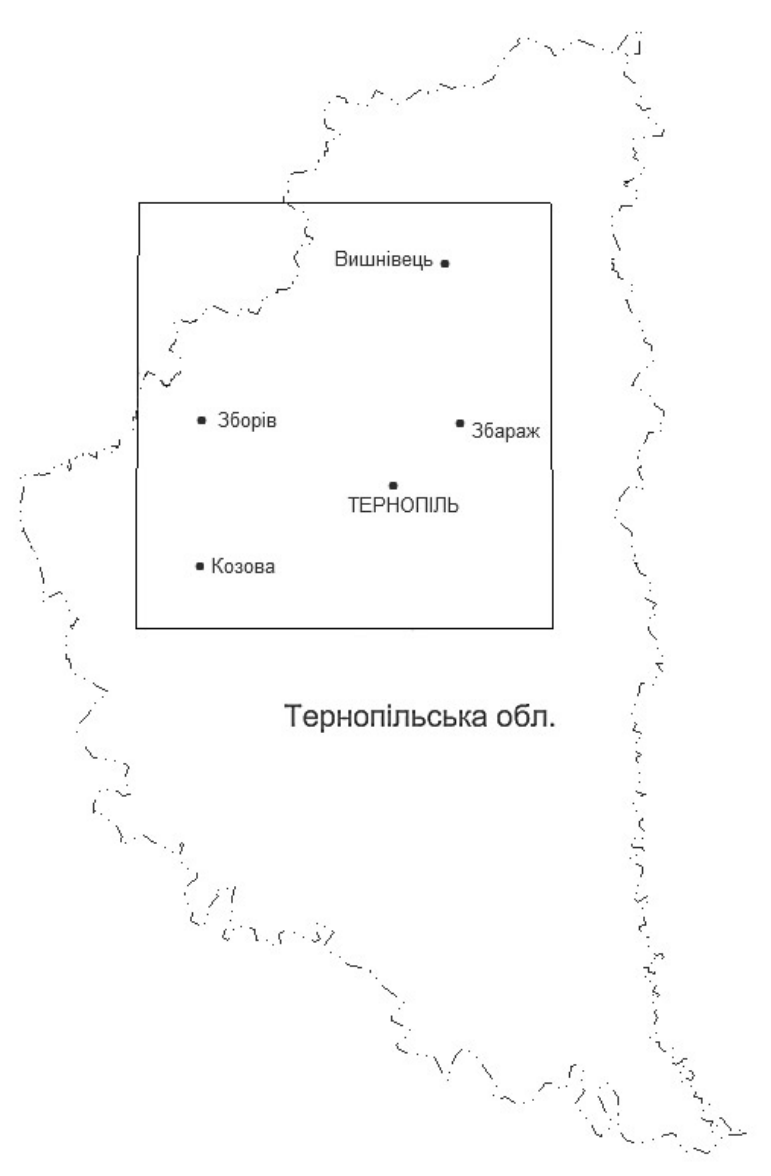

Рис. 1. Оглядова карта досліджуваної території (за [1])

(рис. 1) були завершені у 2008 р. під керівництвом Борисенко Т.С. [1], де автор брав безпосередню участь. Результати, отримані при виконанні цих робіт, викладені у відповідному звіті та покладені в основу даної статті.

\section{ВИКЛАД ОСНОВНОГО МАТЕРІАЛУ}

Протягом палеогенового періоду територія району робіт була сушею, доволі високо піднятою, з якої відбувався знос на північний схід і південний захід.

Неогеновий період вирізнявся підвищеною активністю тектонічної діяльності, море неодноразово наступало та відступало з території району. Розріз неогенової системи на дослідженій території складається з карпатського, баденського та сарматського регіоярусів міоцену (рис. 2), що перекриваються четвертинними відкладами.

У ранньому міоцені територія являла собою високу, сильно розчленовану рівнину з переважанням денудаційних процесів [6]. Осадки, відкладені в попередній час, руйнувалися і зносилися до Передкарпатського басейну.

На початку карпатського часу середнього міоцену територія не покривалася морем, і лише у другій половині карпатію трансгресія моря захопила її південно-західну частину (межиріччя рр. Коропець і Ценів, до широти с. Шибалин). Море було мілким, опрісненим, наступало воно з півдня та південного заходу. В цей же самий час відбулося відмежування північної частини цього басейну, яка сильно опріснилась, в результаті чого відклалися прісноводні вапняки.

Серед карпатських відкладів на дослідженій території найчастіше зустрічаються прісноводні та наземні молюски. Останні, певно, були знесені у морський басейн річковими водами, а прісноводні населяли лагуни та прибережні озера [1]. Для басейну була характерна достатня аерація, помірно тепла температура вод та малі глибини. Глибина верхньої частини субліторалі сягала 20-30 м [6].

Серед відкладів, що датовані карпатієм (рис. 2), найчастіше зустрічаються глини зелені, сіро-зелені, гідрослюдисті, з уламками вапняків; вапняки, інколи слабоглинисті до мергелів, світло-сірі, жовто-сірі, інколи грудкуваті, дрібнокристалічні; піски глинисті до глин, некарбонатні (континентальні прісноводні відклади) і піски та пісковики на зеленому глинистому цементі, зеленувато-жовті, дрібно-, середньозернисті, в підошві - інколи кременева галька (морські відклади) [1].

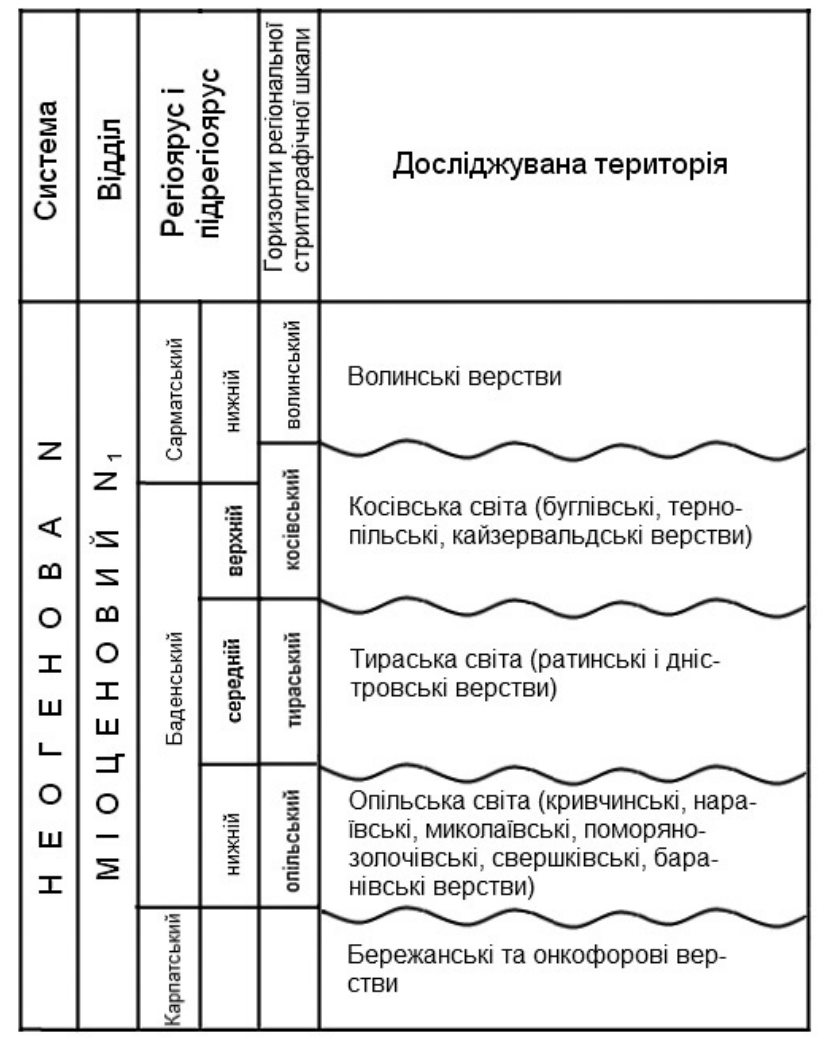

Рис. 2 Стратиграфічна схема неогенових відкладів району досліджень (за [4]) 
На межі карпатію та баденію відбулося короткочасне підняття території над рівнем моря.

У ранньому баденії на Волино-Поділлі межа морського басейну досягала Тернопільського та Теребовлянського районів. Переміщення берегової лінії басейну на схід пов'язане з піднесенням Карпатських гірських споруд.

В результаті тектонічних рухів штирійської фази альпійського орогенезу на початку раннього баденію розпочалася широка трансгресія моря, яка захопила майже всю площу, за вийнятком деяких північних районів. Найбільш широкою трансгресія була на початку раннього баденію. Море було мілким з нормальною солоністю, про що свідчать піщано-літотамнієві відклади та типова стеногалінна фауна. Клімат того часу був помірним, температура води не нижче $18-25^{\circ}[6]$.

Основна маса теригенного матеріалу зносилась з Карпат, які до того часу вже набули вигляду гірської країни, і незначна частина - 3 північного сходу, з області розвитку кристалічних порід.

У ранньобаденському басейні накопичувалися теригенні (піски та глини), карбонатні та карбонатно-теригенні відклади. Серед морської флори раннього баденію значне місце належить літотамнієвим водоростям, які покривали значну частину морського дна. Багатим та різноманітним був тваринний світ, особливо форамініфери та молюски, крім яких басейн заселяли моховатки, корали, морські їжаки, морські зірки, брахіоподи, черви, головоногі молюски, ракоподібні (остракоди, краби), риби, дельфіни та ін.

Температурні умови басейну, за даними вивчення викопних органічних решток, визначено як помірно теплі та нормально солоні (не нижче $30 \%$ ) [1]. Щодо глибини басейну, то, на підставі вивчення фауни молюсків, вона не перевищувала 150-200 м [6]. Ці дані підтверджуються і за результатами літологічних та фаціальних побудов.

У цей же самий час відбувалося відкладення вапняків, переповнених Ervilia pussila P h il . Taкий розвиток одноманітної фауни свідчить про порушення нормальної солоності морського басейну.

Завершення розвитку ранньобаденського басейну, певно, слід пов'язувати з часом, коли у ньому розпочався розвиток ервілій, які досягли масового поширення на значних площах, хоча окрім них спостерігаються кардіїди, моді- оли, грифеї, хляміси, венуси, ізокардії, церити, черви, остракоди, десятиногі раки, але в значно меншій, ніж раніше, кількості. Аналізуючи фауністичний комплекс цього басейну можна зробити висновок про незначне його опріснення (не нижче 17\%) та деяке зменшення його розмірів [6].

Наприкінці ранньобаденського часу, в результаті подальшого проявлення тектонічної діяльності в області Карпатської активної зони та в крайовій частині платформи, почалася поступова регресія моря, кінцевим результатом якої було утворення ряду лагун.

В північній частині району лагуни не мали сполучення з відкритим морем і постійно поповнювалися прісними водами річок та струмків, що впадали до них. На берегах цих лагун росли мангрові ліси. Постійні тектонічні рухи обумовили часту зміну берегової лінії, в результаті чого ліси затоплювалися, а органічний матеріал захоронювався під чохлом теригенних осадків [6]. У подальшому на базі цього органічного матеріалу виникли буровугільні відклади районів Золочева, Ясенова, Дзвинячого та ін.

Серед відкладів, що датовані раннім баденієм (рис. 2), найчастіше зустрічаються вапняки, пісковики, глини та мергелі, переповнені Ervilia pusilla Phil., вапняки водоростеві та органогенно-детритові, піски, мергелі (морські субліторальні відклади), піски та пісковики кварцові та кварц-глауконітові з багатою фауною (морські субліторальні відклади та верх літоралі) та піщано-глинисто-вуглисті відклади (відклади опріснених заток моря та опріснених лагун) [1].

Наприкінці ранньобаденського - на початку середньобаденського часу почалася нова трансгресія моря. Спочатку наступ моря був повільним, через що утворилися окремі лагуни, які мали сполучення з відкритим морем. У лагунах відкладалися хемогенні вапняки, які часто (хоча і не завжди) перекривали гіпсові відклади, що свідчить про певну успадкованість лагун. Води в лагунах були підвищеної солоності.

У середньому баденії в морському басейні відбувалися значні зміни. Берегова лінія, яка оконтурювала його зі сходу, була досить звивистою. Вона досягала довготи м. Тернопіль. Характерною особливістю басейну було значне засолення західної його частини, що відбувалося в умовах жаркого клімату, при постійному притоці морської води [6] .

Серед відкладів, що датовані середнім ба- 
денієм (рис. 2), найчастіше зустрічаються вапняки хемогенні сірі, світло-сірі, жовто-сірі, зеленувато-сірі, різною мірою глинисті, пелітоморфні, інколи каверни з гіпсом, по тріщинах нальоти заліза та марганцю, інколи з тонкою вкрапленістю сірки (відклади басейнів підвищеної солоності) та гіпсово-агнідритові утворення (відклади солоних та гірко-солоних лагунних басейнів) [1].

Наприкінці тираського часу територія повністю звільнилася від моря.

3 початком пізньобаденського часу трансгресія морського басейну на платформу значно розширилася і море займало значно більшу площу, ніж у ранньому баденії. у цей час солоність води стає нормальною і відкладаються органогенні, органогенно-уламкові вапняки та теригенні породи. Характерною особливістю донних карбонатних осадків $€$ розвиток органогенних вапняків, серед яких виділяється багрянковий риф - Товтрова гряда, що складена водоростями роду Lithotamnia, коралами та черепашками різноманітних молюсків. Рифова зона простягається майже паралельно з береговою лінією басейну косівського часу.

Море було мілководним, з доволі сильними течіями та теплою водою, про що свідчить значне поширення водоростей роду Lithotamnia.

Органічний світ пізньобаденського басейну представлений досить багатою флорою та фауною. Родинний склад літотамнієвих водоростей такий самий, як і в ранньому баденії. Численність молюсків, що вживають рослини, дає підставу припустити існування тут багатшої південної рослинності. Серед тварин найширше розвинуті форамініфери і молюски, крім них існували морські їжаки, корали, черви, вищі ракоподібні, дельфіни, моховатки, губки та ін. Кількісний видовий склад тваринного світу цього басейну сягав 500 видів. Наприкінці пізньобаденського часу фауна стає досить збіднілою, що вказує на значне опріснення і поступову ізоляцію басейну [6].

Серед верхньобаденських осадків зустрічаються прошарки туфів, що свідчить про активну вулканічну діяльність у межах Карпат.

В кінці пізньобаденського часу почалося помітне опріснення басейну, яке посилилось на початку раннього сармату. В цьому басейні в буглівський час існувала змішана пізньобаденська та ранньосарматська фауна.

Одночасно з сильним опрісненням, межі ранньосарматського басейну значно розшири- лися на схід і північний схід, що пов'язано з подальшим опусканням території.

Серед відкладів, що датовані пізнім баденієм - раннім сарматом (рис. 2), найчастіше зустрічаються білясті піски з фауною, характерною для умов пониженої солоності, та зелені глауконітові піски, вапняки з великими літотамніями (субліторальні відклади); вапняково-глинисті відклади (відклади нижньої частини субліторалі); глауконітово-кварцові піски та пісковики 3 багатою морською фауною та піщано-вапнякові відклади (відклади літоралі, прибережжя); детритові вапняки та біогерми Товтр (відклади верхньої частини субліторалі) та вапняки глинисті з дрібними літотамніями (відклади літоралі, верхньої частини субліторалі) [1].

Кінець середньоміоценової епохи позначився зміною палеогеографічних умов не лише в Україні, але і в усій Європі. Посилені горотворні процеси в Альпах і Карпатах призвели до відокремлення від Світового океану басейнів, розташованих у Західній та Східній Європі. Північний альпійський крайовий прогин, який з'єднував західний та східний басейни в кінці баденського часу, закінчив своє існування. Відокремлений східний басейн (сарматський) охоплював площу від Віденського району на заході до Аральського моря на сході. Подальший розвиток тектонічних рухів у Карпатській гірській системі в кінці середнього міоцену докорінно змінив фізико-географічні умови південнозахідної частини Східноєвропейської платформи та суміжних територій. В сарматський час відбувається не лише опріснення басейну, а й продовжується його скорочення, що призвело у другу половину сарматського часу до остаточного роз'єднання західного та східного басейнів.

Внаслідокцихрухів пізньобаденськийбасейн з нормальною солоністю відступив. На його місці на початку пізнього міоцену утворився опріснений сарматський басейн у вигляді порівняно вузької затоки північно-західного напрямку. Ця затока відома під назвою Галицько-Подільської. Порівняно з баденською вона вужча та дещо зміщена на схід.

у межах цієї затоки розвиток сарматського моря у зв'язку з наступними проявами карпатського орогенезу був менш тривалим, ніж у Понто-Каспійській області. Волино-Подільська плита, починаючи з другої половини середнього сармату, зазнала диференційованого підняття, в результаті яких море звільнило північнозахідну частину і відступило у південно-східному 
напрямку. Тому на Волино-Поділлі відсутні відклади верхньої частини (а на дослідженій території всього) середнього та верхнього відділів сармату [6].

Ранньосарматське море було мілководним, з сильними течіями, доволі чистим. Клімат на той час був помірно теплим. На початку волинського часу у морському басейні відкладалися переважно теригенні осадки. Наприкінці ранньосарматського часу суттєвого значення набули карбонатні осадки: хемогенні та органогенні вапняки. На вершинах та схилах пізньобаденської рифової гряди наростали нові рифи, які розвивалися і на захід від Товтр, у формі окремих дрібних тіл. У пририфовій смузі відкладалися органогенно-уламкові вапняки та глини.

Серед ранньосарматських відкладів зустрічаються прошарки туфів, що свідчать про поновлення та інтенсивне продовження вулканічної діяльності в межах Карпат.

Морський басейн заселяли безхребетні та хребетні тварини. 3 перших головними були форамініфери та молюски. Не менш важливу роль відігравали моховатки та остракоди. Серед молюсків значно поширеними були гастроподи, представлені численними родами та видами. Відсутність стеногалінних форм свідчить про опріснення вод басейну [6].

Серед типів розрізів, що датовані раннім сарматом (рис. 2), характерними є піщановапняково-глинистий і чисто вапняковий тип та глинисто-мергелистий та вапняковистий тип (відклади середньої частини субліторалі); піщаний тип та піщаний тип з прошарками глин (відклади літоралі, верхньої частини субліторалі); рифові вапняки (відклади верхньої частини субліторалі) [1].

Вірогідно, в кінці ранньосарматського чи у середньосарматський час, територія в результаті тривалих тектонічних рухів атичної фази альпійського тектогенезу була піднята та виведена з-під поверхні моря і стала сушею. Решту неогенового та увесь четвертинний період територія була сушею і повсюди встановилися континентальні умови. В ранньому плейстоцені почалося формування Подільської структурноденудаційної височини на неогенових і крейдових відкладах. Осадконагромадження відбувалося в умовах розчленованого рельєфу. Мають місце пролювіально-делювіальні процеси 3 утворенням конусів виносу на низьких ділянках [1].

\section{ВИСНОВКИ}

В роботі викладена коротка історія геологічного розвитку досліджуваної території та дана загальна характеристика палеогеографічних обстановок, що панували протягом міоцену. Результати спираються на матеріали раніше проведених досліджень та підтверджуються фактичним матеріалом, отриманим за даними численних свердловин і відслонень. Результати робіт є основою для побудови палеогеографічних карт нового покоління.

1. Борисенко Т.С. Геологічна будова та корисні копалини верхньої течії р. Серет. Звіт про геологічне довивчення масштабу 1:200 000 території аркуша М-35-XX (Тернопіль). (Рукопис). Фонд ПДРГП “Північгеологія”. 2008.

2. Власов Б.И., Анисимов В.С., Шестопалов В.М. Геологическая карта листа М-35-XX (Тернополь). Отчёт Тернопольской геологической партии Львовской экспедиции за 1959-60 гг. (Рукопись). Фонд ПДРГП “Північгеологія". 1962

3. Грузман Г.Г. Отчет о полистной геологической съемке планшетов М-35-88-А, В и геологического доизучения планшетов М-35-87-А, Б, В, Г масштаба 1:50 000 за 1983-88 гг. Львовская ГРЭ объединения «Запукргеология”. (Рукопись). Фонд “Західукргеологія” 1988.

4. Матеюк В.В. Легенда к государственной геологической карте Украины масштаба 1:200 000 ВолыноПодольской серии листов. - Ровно, 1995, Аркуш 2 (Кайнозой). - 5 арк.

5. Стратиграфічна схема фанерозойських утворень України до геологічних карт нового покоління. - К., 1993. -53 арк.

6. Стратиграфія України. Т. 10. Неоген - Голов. ред. Бондарчук В.Г. - К.: Наук.думка, 1975. - 272 с.

Центр регіональних геологічних досліджень, Північне державне регіональне геологічне підприємство “Північгеологія", Київ

E-mail: babaski@ukr.net

Рецензент - д-р геол.-мінерал. наук В.Ю. Зосимович 